\title{
Lower prediagnostic serum 25-hydroxyvitamin D concentration is associated with higher risk of insulin-requiring diabetes: a nested case-control study
}

\author{
E. D. Gorham • C. F. Garland • A. A. Burgi • S. B. Mohr • \\ K. Zeng • H. Hofflich • J. J. Kim • C. Ricordi
}

Received: 30 May 2012 / Accepted: 8 August 2012 /Published online: 7 September 2012

(C) Springer-Verlag 2012

\begin{abstract}
Aims/hypothesis Low serum 25-hydroxyvitamin D [25 $(\mathrm{OH}) \mathrm{D}]$ concentration may increase risk of insulinrequiring diabetes.

Methods A nested case-control study was performed using serum collected during 2002-2008 from military service members. One thousand subjects subsequently developed insulin-requiring diabetes. A healthy control was individually matched to each case on blood-draw date ( \pm 2 days), age ( \pm 3 months), length of service ( \pm 30 days) and sex. The median elapsed time between serum collection and first diagnosis of diabetes was 1 year (range 1 month to 10 years). Statistical analysis used matched pairs and conditional logistic regression.

Results ORs for insulin-requiring diabetes by quintile of serum $25(\mathrm{OH}) \mathrm{D}$, from lowest to highest, were $3.5(95 \% \mathrm{CI}$ $2.0,6.0), 2.5(1.5,4.2), 0.8(0.4,1.4), 1.1(0.6,2.8)$ and 1.0 (reference) $\left(p_{\text {trend }}<0.001\right)$. The quintiles (based on fifths
\end{abstract}

E. D. Gorham $(\bowtie) \cdot$ C. F. Garland · A. A. Burgi · S. B. Mohr •

K. Zeng · J. J. Kim

Naval Health Research Center,

140 Sylvester Road,

San Diego, CA 92106-3521, USA

e-mail: Edward.Gorham@med.navy.mil

E. D. Gorham • C. F. Garland · S. B. Mohr

Department of Family and Preventive Medicine,

University of California San Diego,

La Jolla, CA, USA

H. Hofflich

Division of Internal Medicine, Department of Medicine,

University of California San Diego,

La Jolla, CA, USA

C. Ricordi

Miami Diabetes Research Institute,

Department of Surgery and Cell Transplant Center,

University of Miami Miller School of Medicine,

Hollywood, FL, USA using serum $25(\mathrm{OH}) \mathrm{D}$ concentration in the controls) of serum $25(\mathrm{OH}) \mathrm{D}$ in $\mathrm{nmol} / \mathrm{l}$, were $<43$ (median 28 ), 43-59 (median 52), 60-77 (median 70), 78-99 (median 88) and $\geq 100$ (median 128).

Conclusions/interpretation Individuals with lower serum $25(\mathrm{OH}) \mathrm{D}$ concentrations had higher risk of insulinrequiring diabetes than those with higher concentrations. A 3.5-fold lower risk was associated with a serum 25 $(\mathrm{OH}) \mathrm{D}$ concentration $\geq 60 \mathrm{nmol} / \mathrm{l}$.

Keywords 25-Hydroxyvitamin D · Insulin-requiring diabetes $\cdot$ Military populations $\cdot$ Nested case-control study . Type 1 diabetes mellitus

\section{Abbreviation \\ 25(OH)D 25-Hydroxyvitamin D}

\section{Introduction}

There are approximately 40,000 new cases of type 1 diabetes in the USA annually, including an estimated 15,600 in children [1] and 24,400 in adults [2]. The overall annual incidence rate in the US population is approximately 13 per 100,000 [2], similar to the rate of 12 per 100,000 personyears in US military service members [3]. Annual agestandardised incidence rates of type 1 diabetes vary from a low in the tropics of 0.5 per 100,000 (in Venezuela, latitude $\left.9^{\circ} \mathrm{N}\right)$ to a high of 60 per 100,000 in Finland $\left(60^{\circ} \mathrm{N}\right)[4,5]$.

An association has been proposed between vitamin $\mathrm{D}$ deficiency and higher risk of type 1 diabetes [5-7]. The EURODIAB case-control study reported that children who did not receive a vitamin $\mathrm{D}$ supplement during infancy had 1.5 times the risk of type 1 diabetes as those who received a vitamin $\mathrm{D}$ supplement [7]. That study had information only on the use of vitamin D supplements, not serum 25-hydroxyvitamin D 
[25(OH)D] concentrations. Hypponen et al reported that children in a prospective cohort study who received $<2,000 \mathrm{IU} /$ day of vitamin D through vitamin D supplements had 4.5 times higher risk than those with intake $\geq 2,000 \mathrm{IU} /$ day [6]. These studies depended on self-reported questionnaires, which may have limited their validity. Two ordinary case-control studies found that serum $25(\mathrm{OH}) \mathrm{D}$ was inversely associated with risk of insulin-requiring diabetes $[8,9]$, but a third study found no association [10].

\section{Methods}

Study population This was a nested case-control study of prediagnostic serum from military service members on active duty who were screened by a US Department of Defense serological surveillance programme. One-thousand consecutive new cases of insulin-requiring diabetes and 1,000 healthy controls were identified. Controls were individually matched to cases according to date that the blood sample was drawn ( \pm 2 days), age ( \pm 3 months), length of military service ( \pm 30 days), sex and whether the control was on active duty when the case was diagnosed. Serum samples were collected and frozen during 2002-2008. Cases were ascertained during 2002-2011. The 3-year-longer interval for case and control ascertainment allowed time to elapse between the date that blood was collected and date of occurrence of a case. The median interval between collection of the blood sample and diagnosis was 1 year and the interquartile range was also 1 year. The longest interval was 10 years and the shortest was $<12$ months. Procedures were in accordance with Department of Defense Directive 6490.2 and Instruction 6490.3 [11]. The samples were frozen in 0.5$\mathrm{ml}$ portions and stored in the Department of Defense Serum Repository. All data were stored in the Defense Medical Surveillance System [11]. This was an exempt protocol of anonymised data, so informed consent was not required.

This study was conducted in accordance with the ethical standards of the relevant Department of Defense Institutional Review Board and the Helsinki Declaration of 1975, as revised in 1983, and approval was obtained from an Institutional Review Board on 5 November 2009.

Case ascertainment and definition Cases were ascertained from a database that included care in all Department of Defense hospitals and clinics and civilian facilities serving military service members worldwide. A case was defined as an active-duty military service member diagnosed with insulin-requiring diabetes (ICD 9-CM codes 250.0x$250.9 x$, where $x=1$ or 3 ; see www.icd9data.com/2007/ Volume1/240-279/250-259/250/default.htm). The case definition required: (1) being hospitalised with a discharge diagnosis of insulin-requiring diabetes certified by a physician;
(2) having three or more clinic or outpatient medical care visits with a primary diagnosis by a physician of insulin-requiring diabetes during a 12-month period; or (3) having seven or more outpatient medical care visits with a primary diagnosis of insulin-requiring diabetes by a physician. The most recent serum sample preceding the date of diagnosis was obtained.

Laboratory procedures Blood samples were collected in plain tubes and allowed to clot. Serum was separated from cells by centrifugation at approximately $1,400 \mathrm{~g}$ for $10 \mathrm{~min}$. Serum was divided into $0.5 \mathrm{ml}$ volumes in polypropylene cryogenic vials, frozen at $-70^{\circ} \mathrm{C}$ and stored in freezers equipped with temperature alarms. Serum was analysed by a 25(OH)D analysis laboratory (Heartland Laboratories, Ames, IA, USA), using a US Food and Drug Administrationapproved direct, competitive chemiluminescence immunoassay, the DiaSorin LIAISON Assay (DiaSorin, Stillwater, MN, USA) [12]. The inter- and intra-assay coefficients of variation were $12.4 \%$ and $5.4 \%$, respectively [12]. Measurements were validated according to the Vitamin D External Quality Assessment Scheme. The laboratory had no knowledge of case or control status of the samples.

Statistical analysis Matched-pairs ORs were calculated as the ratio of discordant pairs. Statistical significance was calculated using the McNemar test. Differences in means and medians were tested using the Mann-Whitney $U$ test.

Quintiles of serum 25(OH)D were determined based on the distribution of $25(\mathrm{OH}) \mathrm{D}$ concentrations in the controls. Analyses were performed using SAS-PC, version 9.1 (SAS Institute, Cary, $\mathrm{NC}$, USA). The criterion for statistical significance was $p \leq 0.05$, two-tailed.

\section{Results}

The risk of insulin-requiring diabetes was 3.5 times higher in individuals with the lowest $25(\mathrm{OH}) \mathrm{D}$ concentration compared with those with the highest (Fig. 1). ORs by quintile of serum 25(OH)D concentration, from lowest to highest, were $3.5(95 \%$ CI $2.0,6.0), 2.5(1.5,4.2), 0.8(0.4,1.4), 1.1$ $(0.6,2.8)$ and 1.0 (reference), respectively $\left(p_{\text {trend }}<0.001\right)$ (Fig. 1). The quintiles of serum $25(\mathrm{OH}) \mathrm{D}$, in $\mathrm{nmol} / \mathrm{l}$, were $<43$ (median 28), 43-59 (median 52), 60-77 (median 70), 78-99 (median 88) and $\geq 100$ (median 128). AfricanAmericans were more likely to be cases than individuals of other races (Table 1). The mean serum 25(OH)D concentration was substantially lower in individuals who developed diabetes $(62.2 \mathrm{nmol} / \mathrm{l})$ than in healthy controls $(72.5 \mathrm{nmol} / \mathrm{l})(p<0.0001)$ (Table 2$)$. The association was present within all three racial groups (Table 2).

After adjustment for race, the ORs for the lowest vs highest quintile of $25(\mathrm{OH}) \mathrm{D}$, were $1.9(95 \%$ CI $1.4,2.7)$, 


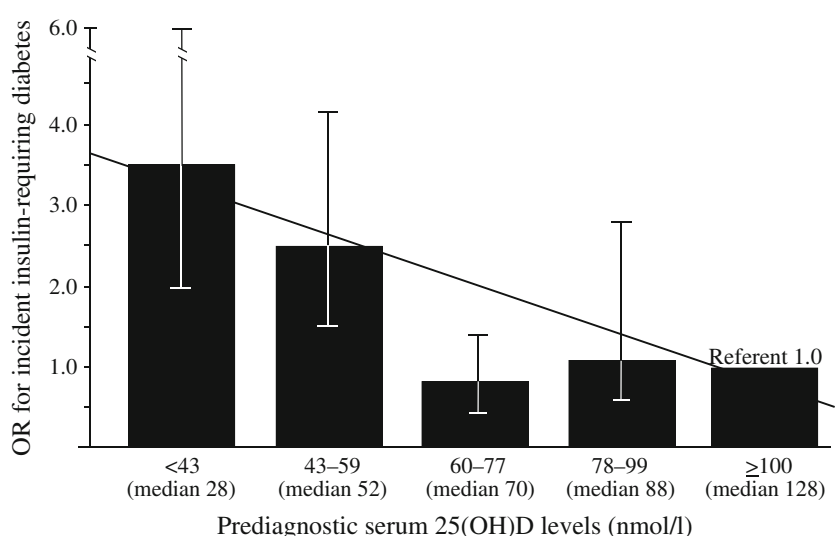

Fig. 1 ORs and 95\% CIs for insulin-requiring diabetes by prediagnostic serum $25(\mathrm{OH}) \mathrm{D}$ concentration, active-duty military service members, USA, 2002-2011. Data were generated using McNemar matched-pairs analysis in which healthy controls were individually matched to cases by the date the blood sample was drawn ( \pm 2 days), age ( \pm 3 months), sex and length of military service ( \pm 30 days). Cases and controls in each pair were on active duty when the case was diagnosed. The number of discordant pairs, from lowest to highest quintile (except the reference quintile defined as having an OR of 1.0 ), were $52 / 15,50 / 20,33 / 26$ and $34 / 32$. The regression equation was: $y=-0.026 x+3.6$; $p$ for linear trend $<0.001$

$1.7(1.3,2.3), 1.1(0.8,1.6), 1.2(0.9,1.6)$ and 1.0 (reference) $(p<0.0001$ for top vs bottom quintile). The OR of insulinrequiring diabetes for black compared with white subjects was $1.6(1.2,2.0)(p<0.001)$.

\section{Discussion}

Individuals with a low serum $25(\mathrm{OH}) \mathrm{D}$ concentration had a substantially higher risk of developing insulin-requiring

Table 1 Characteristics of the study population of 1,000 insulinrequiring diabetes cases and 1,000 matched controls, active-duty US military service members, 2002-2011

\begin{tabular}{|c|c|c|c|c|}
\hline \multirow[t]{2}{*}{ Characteristic } & \multicolumn{2}{|c|}{ Cases } & \multicolumn{2}{|c|}{ Controls } \\
\hline & $n$ & $\%$ & $n$ & $\%$ \\
\hline \multicolumn{5}{|l|}{ Race $^{\mathrm{a}}$} \\
\hline White & 561 & 56.1 & 669 & 66.9 \\
\hline Black & 276 & 27.6 & 163 & 16.3 \\
\hline Other & 163 & 16.3 & 168 & 16.8 \\
\hline \multicolumn{5}{|l|}{ Age in years ${ }^{b}$} \\
\hline $17-19$ & 56 & 5.6 & 59 & 5.9 \\
\hline $20-22$ & 167 & 16.7 & 161 & 16.1 \\
\hline $23-24$ & 125 & 12.5 & 128 & 12.8 \\
\hline $25-29$ & 221 & 22.1 & 221 & 22.1 \\
\hline $30-34$ & 135 & 13.5 & 136 & 13.6 \\
\hline $35+$ & 296 & 29.6 & 295 & 29.5 \\
\hline
\end{tabular}

${ }^{\mathrm{a}} \chi^{2}=38.6, p<0.0001 ;{ }^{\mathrm{b}} \chi^{2}=0.23 p=0.99$
Table 2 Prediagnostic serum 25(OH)D concentrations in the study population of 1,000 insulin-requiring diabetes cases and 1,000 matched controls, active-duty US military service members, 2002-2011

\begin{tabular}{|c|c|c|c|}
\hline \multirow[t]{2}{*}{ Race } & \multicolumn{2}{|c|}{ Serum 25(OH)D (nmol/l) } & \multirow[t]{2}{*}{$p$ value } \\
\hline & Cases & Controls & \\
\hline White & $62.2(31.8)$ & $72.5(33.0)$ & $\leq 0.0001$ \\
\hline Black & $41.8(26.0)$ & $46.5(24.8)$ & $\leq 0.01$ \\
\hline Other & $60.8(28.5)$ & $69.2(33.2)$ & $\leq 0.01$ \\
\hline All races & $62.2(31.8)$ & $72.5(33.0)$ & $\leq 0.0001$ \\
\hline
\end{tabular}

Results are presented as mean (SD)

diabetes than those with a higher concentration. This is consistent with two previous case-control studies of serum 25(OH)D [8, 9], but not a third [10]. An inverse association between serum 25(OH)D and risk of insulin-requiring diabetes was present in the same direction and was statistically significant in all race groups.

There was a substantial inverse association comparing the lowest quintile with the third quintile (Fig. 1). Based on the present study, it may be that no further reduction in risk would be expected once a serum $25(\mathrm{OH}) \mathrm{D}$ concentration of $>60 \mathrm{nmol} / \mathrm{l}$ has been attained.

Limitations of this study include the possibility that some of the individuals with insulin-requiring diabetes may have had a disorder that some might regard as complicated or severe forms of type 2 diabetes [13]. Cases in the present study were included solely because they were dependent on insulin.

Only one serum sample was used, to control costs of the study. The findings could have been different if the study had analysed the earliest samples collected from each individual, rather than the most recent. However, the association might have been missed if the effect of vitamin D deficiency is short lived. Since insulin-requiring diabetes occurs even in young children [1], the time interval between exposure and diagnosis is probably rather short.

There may be an association between higher BMI and higher risk of type 1 diabetes [14, 15], but obesity is only a modest risk factor for type 1 diabetes, at least in children and adolescents [15]. BMI values of the individuals in this study were not provided in the available database. Therefore, caution should be exercised when interpreting the results, since the higher risk of insulin-requiring diabetes observed in individuals with low serum $25(\mathrm{OH}) \mathrm{D}$ could be partly due to their having a higher BMI. On the other hand, all subjects in this study were active-duty military personnel who were required to meet annual standards for body weight. The required BMI in the military for males is $\leq 26 \mathrm{~kg} / \mathrm{m}^{2}$ and for females it is $\leq 28 \mathrm{~kg} / \mathrm{m}^{2}$. These maxima are well below the usual criterion of $\geq 30 \mathrm{~kg} / \mathrm{m}^{2}$ for obesity.

The results of this study should be generalised to the US population only with caution. Patients were not examined 
specifically for the purposes of this study. This could have contributed to misdiagnosis.

This study used prediagnostic serum for analysis of the $25(\mathrm{OH}) \mathrm{D}$ concentration. This is an advantage over preceding studies that analysed serum collected after diagnosis of diabetes. A further advantage of this study is its large sample size, greater than that of all known previous studies of this association combined.

Higher serum $25(\mathrm{OH}) \mathrm{D}$ concentration provides the substrate for biosynthesis of $1,25(\mathrm{OH})_{2} \mathrm{D}$, which inhibits occurrence of insulin-requiring diabetes in animal models [16]. Vitamin D deficiency is associated with major effects on the innate immune system [17]. This could potentially influence the risk of diabetes by reducing risk of infection of islet cells. However, vitamin-D-deficient and VDR-KO mice do not have known major abnormalities of the immune system, except for minor effects on dendritic cell markers [17]. Individuals in this study who had serum levels of $25(\mathrm{OH}) \mathrm{D}$ greater than $100 \mathrm{nmol} / \mathrm{l}$ had a $70 \%$ lower risk of developing insulindependent diabetes than those with levels below $43 \mathrm{nmol} / \mathrm{l}$. While the results are intriguing, caution should be exercised when supplementing with very large doses of vitamin D [18].

Acknowledgements The authors express their deepest special thanks and appreciation to A. Eick, Special Studies Lead, at the Armed Forces Health Surveillance Center, for her invaluable assistance, expert advice and thoughtful consultation and review throughout this project.

The authors also thank R. Horst of Heartland Assays, Ames, Iowa, for performing the $25(\mathrm{OH}) \mathrm{D}$ assays. Thanks to $\mathrm{S}$. Davis of the Naval Health Research Center for assistance in the preparation of this manuscript.

Funding This research was supported by a Congressional allocation to the University of Miami Diabetes Research Institute (Miami, FL, USA), through the Department of the Navy, Bureau of Medicine and Surgery, under Work Unit No. 60126. The views expressed in this report are those of the authors and do not represent an official position of the Department of the Navy, Department of Defense, or the US Government.

Duality of interest The authors declare that there is no duality of interest associated with this manuscript.

Contribution statement EDG and CFG designed the study, interpreted the data and drafted the article. AAB drafted the protocol and obtained the data. SBM analysed the data. KZ analysed the data and performed the literature review. HH helped interpret the data. JJK coauthored the literature review, participated in the analysis and interpretation of the data and played an important role in drafting the article. CR contributed to the conception of the study and securing its support. All authors reviewed the article and approved the final draft.

\section{References}

1. Dabelea D, Bell RA, D'Agostino RB Jr et al (2007) Incidence of diabetes in youth in the United States. JAMA 297:2716-2724

2. Centers for Disease Control and Prevention (2011) National Diabetes Factsheet: national estimates and general information on diabetes and prediabetes in the United States. Available from www.cdc.gov/diabetes/pubs/pdf/ndfs_2011.pdf. Accessed January 2012

3. Gorham ED, Barrett-Connor E, Highfill-McRoy RM et al (2009) Incidence of insulin-requiring diabetes in the US military. Diabetologia 52:2087-2091

4. Soltesz G, Patterson CC, Dahlquist G (2007) Worldwide childhood type 1 diabetes incidence-what can we learn from epidemiology? Pediatr Diabetes 8(Suppl 6):6-14

5. Mohr SB, Garland CF, Gorham ED, Garland FC (2008) The association between ultraviolet $\mathrm{B}$ irradiance, vitamin $\mathrm{D}$ status and incidence rates of type 1 diabetes in 51 regions worldwide. Diabetologia 51:1391-1398

6. Hypponen E, Laara E, Reunanen A, Jarvelin MR, Virtanen SM (2001) Intake of vitamin D and risk of type 1 diabetes: a birthcohort study. Lancet 358:1500-1503

7. The EURODIAB Substudy 2 Study Group (1999) Vitamin D supplement in early childhood and risk for type I (insulin-dependent) diabetes mellitus. Diabetologia 42:51-54

8. Borkar VV, Verma S, Devidayal, Bhalla AK (2010) Low levels of vitamin $\mathrm{D}$ in North Indian children with newly diagnosed type 1 diabetes. Pediatr Diabetes 11:345-350

9. Bener A, Alsaied A, Al-Ali M et al (2009) High prevalence of vitamin D deficiency in type 1 diabetes mellitus and healthy children. Acta Diabetol 46:183-189

10. Bierschenk L, Alexander J, Wasserfall C, Haller M, Schatz D, Atkinson M (2009) Vitamin D levels in subjects with and without type 1 diabetes residing in a solar rich environment. Diabetes Care 32:1977-1979

11. Rubertone MV, Brundage JF (2002) The Defense Medical Surveillance System and the Department of Defense serum repository: glimpses of the future of public health surveillance. Am J Public Health 92:1900 1904

12. Wagner D, Hanwell HE, Vieth R (2009) An evaluation of automated methods for measurement of serum 25-hydroxyvitamin D. Clin Biochem 42:1549-1556

13. Wasserfall CH, Atkinson MA (2006) Autoantibody markers for the diagnosis and prediction of type 1 diabetes. Autoimmun Rev $5: 424-428$

14. Fourlanos S, Harrison LC, Colman PG (2008) The accelerator hypothesis and increasing incidence of type 1 diabetes. Curr Opin Endocrinol Diabetes Obes 15:321-325

15. Verbeeten KC, Elks CE, Daneman D, Ong KK (2011) Association between childhood obesity and subsequent type 1 diabetes: a systematic review and meta-analysis. Diabet Med 28:10-18

16. Zella JB, McCary LC, DeLuca HF (2003) Oral administration of 1,25-dihydroxyvitamin D3 completely protects NOD mice from insulin-dependent diabetes mellitus. Arch Biochem Biophys 417:77-80

17. Hewison M (2012) An update on vitamin D and human immunity. Clin Endocrinol 76:315-325

18. Hathcock JN, Shao A, Vieth R, Heaney R (2007) Risk assessment for vitamin D. Am J Clin Nutr 85:6-18 